has been founding his remark on the old map, in the first or second edition of that work, showing only the earlier glaciation on land, and not at all the subsequent ice-movement along the coast? In any case, as Prof. Hull seems to throw doubt on one's accuracy in the matter, it becomes necessary to point out that the mistake is entirely his own, as doubtless he will readily acknowledge.

\title{
THE AGE OF THE RHYOLITES OF COUNTY ANTRIM.
}

SIR, - The "Proceedings of the Geologists' Association" for August, 1895 (vol. xiv, p. 152), contain a communication made by myself to Mr. R. Lloyd Praeger respecting the probable contemporaneity of the rhyolites of county Antrim and the granite of the Mourne Mountains. This statement was based on notes made by me early in the year, and I had learned, from conversation with Mr. W. W. Watts, that similar views were current among the members of the staff of the Geological Survey of Ireland. Hence the form in which Mr. Praeger utilized the information sent to him.

I wrote, however, in June, before I had received my copy of the Geologioal Magazine for that month, and hence Mr. MeHenry's clear statement of his belief,' though by that time published, was not directly referred to. As soon as I read his paper, I forwarded an account of it, and a withdrawal of any reference to myself, to Mr. Praeger, who revised the amended sentences on his proof's ; but the correction appears to have been overlooked in the press of business connected with a summer excursion of the Association. I make this explanation, since the passage, as published in August, is distinctly unfair to Mr. McHenry's paper, which has thrown such light upon the question.

Grenville A. J. Cole.

Royal College of Science for Ireland, DuBLIN ; Uctober 13th, 1895.

\section{OBITUAEY. \\ ROBERT FITCH, F.S.A., F.G.S. \\ Born Ocrober 21st, $1802 . \quad$ Died April 4th, 1895.}

Geologr, like other branches of Natural History, has owed much of its progress to the zeal of collectors. Of these, one of the most painstaking and successful was the late Robert Fitch, who, in addition to a most valuable collection of antiquities, had gathered together a very fine series of fossils from the Crag and Chalk of Norfolk. He was born at Ipswich, on October 21st, 1802, educated at the Grammar School, and apprenticed to a cbemist and druggist in the town. Pursuing this occupation he settled in Norwich, in 1827, in partnership with Mr. Sheriff Chambers, and continued until he was over 90 years of age to take an active interest in business. From an early date he took great interest in fossils, and his specimens were always at the service of those engaged in palæontological studies.

$\mathrm{He}$ seldom wrote on geological subjects, his chief literary contributions being to the "Transactions of the Norfolk Archæological Society." In 1836, however, he communicated to the Geological Society an account of the discovery of the tooth of a Mastodon in

1 "On the Age of the Trachytic Rocks of Antrim," GEol. MAG. 1895, p. 264. 